\section{Ivemark syndrome-a rare entity with specific anatomical features}

\author{
ADRIAN HRUSCA ${ }^{1}$, ANDREEA LIANA RACHISAN ${ }^{1}$, BOGDAN LUCIAN ${ }^{2}$, \\ SIMONA OPRITA ${ }^{3}$, SIMONA MANOLE ${ }^{4}$, SIMONA CAINAP $^{1}$
}

\begin{abstract}
Ivemark syndrome (IS) is a rare embryological disorder which results from failure of development of the left-right asymmetry of organs. It is often associated with cardiac and other organ abnormalities, which are the usual causes of death in early neonatal life. We report a 3 months old girl with IS with dextrocardia, transposition of the great vessels, atrio-ventricular connection, total anomalous pulmonary venous drainage, a right atrial and right pulmonary isomerism, a midline liver, a midline gallbladder, asplenia, intestinal malrotation and vena cava anomalies. To our knowledge, complete right heterotaxia syndrome has been rarely described in literature. Lateralization defects such as situs inversus, asplenia or polysplenia due to defective left-right axis development are considered as defects of the primary developmental field. Therefore, additional malformations in IS can be synchronic defects in the primary developmental field rather than causally independent malformations.
\end{abstract}

(Rev Med Chile 2015; 143: 383-386)

Key words: Congenital abnormalities; Heterotaxy syndrome; Ivemark syndrome; Situs ambiguous with asplenia.

\section{Síndrome de Ivermark. Informe de un caso}

El sindrome de Ivermark es un desorden embriológico raro resultante de una falla en el desarrollo de la asimetría izquierda y derecha de los órganos. Usualmente se asocia con anomalías cardíacas y de otros órganos, que son la causa usual de muerte en la vida neonatal. Presentamos una niña de 3 meses con dextrocardia, trasposición de los grandes vasos, comunicación aurículo-ventricular, drenaje anómalo total de la vena pulmonar, isomerismo de la aurícula y pulmón derecho, hígado y vesícula en la línea media, asplenia, malrotación intestinal y anomalías de la vena cava. Una heterotaxia derecha completa ha sido raramente descrita en la literatura. Los defectos de lateralización como situs inverso, asplenia o poli esplenia causados por defectos en el desarrollo izquierda derecha son considerados como defectos del campo de desarrollo primario. Por lo tanto, las manifestaciones adicionales del sindrome de Ivemark pueden ser defectos sincrónicos del campo de desarrollo primario más que malformaciones causalmente independientes.

\author{
'Department of Pediatrics \\ II, University of Medicine \& \\ Pharmacy "Iuliu Hatieganu" Cluj- \\ Napoca, Romania. \\ ${ }^{2}$ Department of Pediatrics, Baia- \\ Mare County Hospital, Romania. \\ ${ }^{3}$ Department of Cardiology, \\ Cluj-Napoca County Hospital, \\ Cluj-Napoca, Romania. \\ ${ }^{4}$ Department of Radiology, \\ Cluj-Napoca County Hospital, \\ Cluj-Napoca, Romania. \\ Conflicts of interest: nothing to \\ disclose \\ Recibido el 16 de octubre \\ de 2014, aceptado el 22 de \\ diciembre de 2014 \\ Corresponding author: \\ Andreea Liana Rachisan \\ 3-5 Crisan Street, Cluj-Napoca \\ 400371 Romania \\ 0040-755.511.115 \\ andreea_rachisan@yahoo.com
}

ongenital heart diseases (CHD) affect approximately $0.75-0.9 \%$ of newborns and are the leading cause of death in neonates and infants ${ }^{1}$. Among the various kinds of CHD, heterotaxy syndromes (HS) are the most complex.
They appear in approximately 1 to 5,000-7,000 of live births with $\mathrm{CHD}^{2}$. Right-atrial isomerism (RAI) or Ivemark syndrome (IS) is a heterotaxy and plurimalformative syndrome with modification of the left-right axis. The result is a complex 
heart malformation and anomalies of the thoracic and abdominal organs. The revealing element for the diagnosis is asplenia. This condition is rarely seen in adults, because the majority of children with RAI do not survive beyond their first year of life.

\section{Case report}

A 3 months old full-term female was born after an apparently normal pregnancy and labor. The weight at birth and the Apgar score were unknown. The mother was G1P1A0 with no significant family history. With an apparent normal development, the patient was hospitalized at the age of 2 months in a pediatric department. The reasons for hospitalization were cyanosis and altered general health (weight loss and anorexia) with leukocytosis (white blood cell count, 21.500/ $\mathrm{mm}^{3}$ ). On physical examination, a $3^{\text {rd }}$ degree cardiac murmur was identified. Thus, a plain thoracic radiograph showed dextrocardia. Echocardiography showed a complex congenital heart disease. A computed tomographic (CT) examination was performed. A dextrocardia with common atrioventricular connection Rastelli $C$, transposition of the great vessels with total anomalous pulmonary venous drainage (Figure 1 A, B) was identified. The superior vena cava had an aneurysmal dilatation (Figure 2A). The liver was median situated, while the spleen was not visualized (Figure 2B).
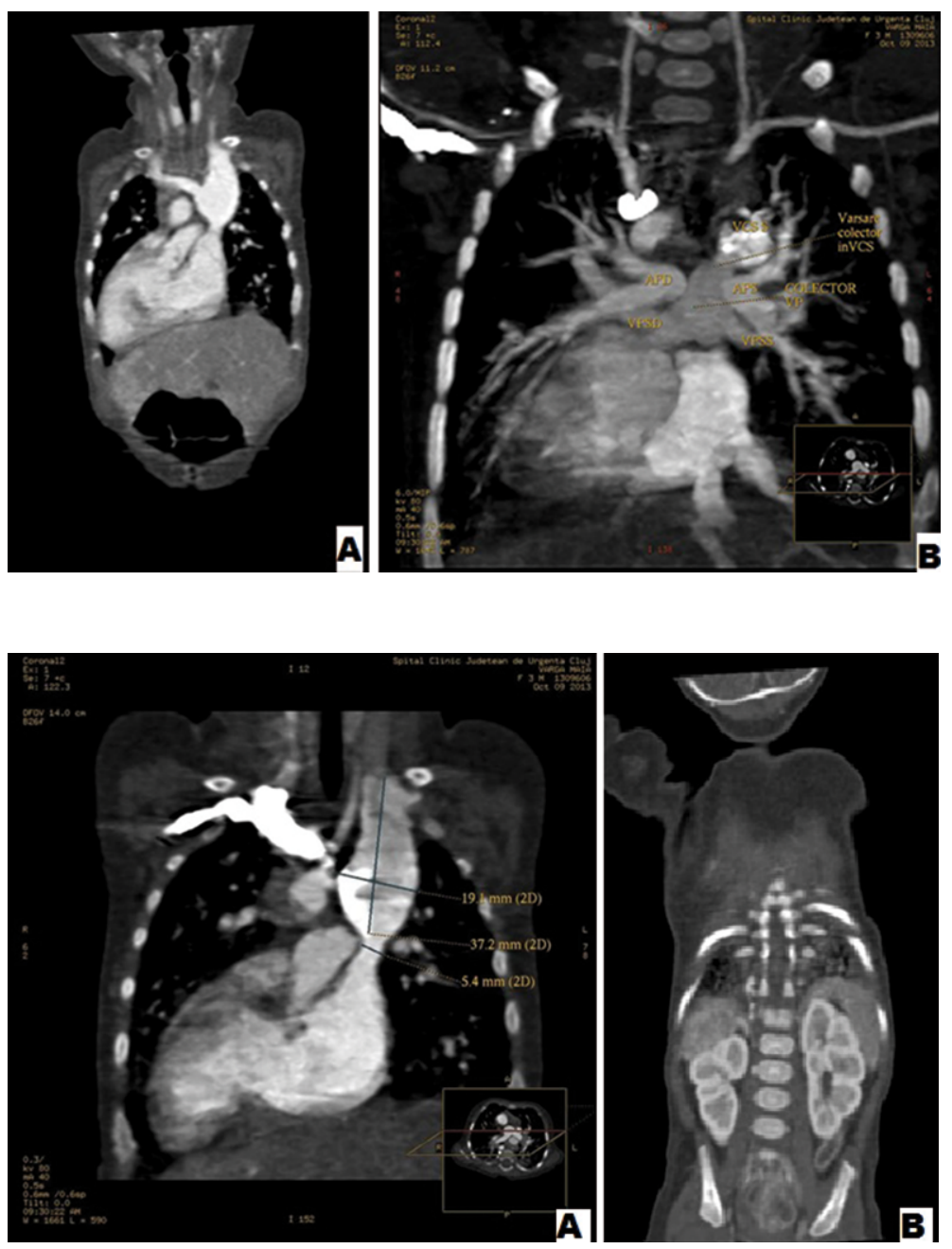

Figure 1. (A) Coronal section revealing dextrocardia.(B) Transposition of the great vessels with total anomalous pulmonary venous drainage and a common pulmonary collector.
Figure 2. (A) CT with contrast showing the aneurysmal dilatation of the superior vena cava. (B) Coronal section showing median liver and asplenia. 


\section{Discussion}

Heterotaxy syndromes are rare congenital anomalies with multi-system involvement. Grouped under the broad category of situs ambiguous defects, these often pose diagnostic difficulties due to their varied and confusing anatomy. HS includes a wide range of malformations including both cardiac and extracardiac manifestations. In the majority of cases major cardiac malformations reveal this condition in newborns. This is the reason for the high mortality rate $(60 \%)$ before reaching the $1^{\text {st }}$ year of age ${ }^{3}$. Only 5 to $10 \%$ of the patients with IS reach adulthood ${ }^{4}$. It is seen more in males, presents mostly with cyanotic heart disease and patients are immunocompromised due to absent spleen. Neonates with right isomerism typically show a single atrium, a single right ventricle and an atrioventricular connection often associated with atrioventricular valve regurgitation. Pulmonary venous obstruction due to total anomalous pulmonary venous drainage should be precisely diagnosed. The most frequently found hepatic anomaly is a median liver. The complete common mesentery consists of the mesentery rotation being stopped at $90^{\circ}$. The colon is entirely situated on the left side, the small intestine and stomach are placed on the right side of the median line ${ }^{5}$.

IS is primarily induced by disorders of leftright axis determination during early embryological development. This condition probably arises from a defect in the lateralization, thus causing development disorder in asymmetric organs . $^{6}$. Right isomerism is a condition where production of left determinants is low and/or nodal flow is abnormal. As a result, the left signal is not activated in both sides.

In our literature research, we came across several reviews and three case presentations related to IS. We compared the findings of our case with the findings of the RAI in these case reports. Petitpierre et al. ${ }^{5}$ reported a case of pulmonary embolism in an adult revealing an IS. Himanshu et al. ${ }^{7}$ reported a case of Ivemark syndrome presenting dysphagia. Chahed et al. ${ }^{8}$ described the presence of a pancreatic cyst in an IS.

Most patients with right isomerism succumb within the first year of life due to cardiovascular compromise 9 . Moreover, susceptibility to infection still remains a problem. Survival into adulthood can be explained by less severe pulmonary stenosis, absence of arrhythmias or overwhelming infections ${ }^{7}$. Sepsis due to asplenia, sudden death and cardiac arrhythmias may potentially be related to major causes of late mortality ${ }^{10}$. This case confirms that IS is one of the most severe forms of CHD. The prognosis remains poor despite modern surgical techniques. Prenatal diagnosis will allow appropriate counseling for families and will facilitate the prompt treatment immediately after birth.

\section{Conclusion}

Therefore, given the high mortality rate in patients with RAI it seems prudent to reassess the management of these patients. It is crucial to reveal the anatomical features in these patients by using imaging modalities because being aware of them prior to surgery and invasive intervention prevents the possible risks and complications.

\section{References}

1. Van der Linde D, Konings EE, Slager MA, Witsenburg M, Helbing WA, Takkenberg JJ, et al. Birth prevalence of congenital heart disease worldwide: A systematic review and meta-analysis. J Am Coll Cardiol 2011; 58: 2241-7.

2. Shiraishi I, Ichikawa H. Human Heterotaxy SyndromeFrom Molecular Genetics to Clinical Features, Management, and Prognosis. Circ J 2012; 76: 2066-75.

3. Bartram U, Wirbelauer J, Speer CP. Heterotaxy syndrome-asplenia and polysplenia as indicators of visceral malposition and complex congenital heart disease. Biol Neonate 2005; 88 (4): 278-90.

4. Ahmed SA, Zengeya S, Kini U, Pollard AJ. Familial isolated congenital asplenia: case report and literature review. Eur J Pediatr 2010; 169 (3): 315-8.

5. Petitpierre F, Alberti N, Raffray B, Veron A, Perez JT, Lasserre AS. Acute pulmonary embolism revealing Ivemark syndrome in an adult. Diagnostic and Interventional Imaging 2013; 94: 333-5.

6. Van de Perre FM, Vanhoenacker C, Petr'e J, Van Doorn, De Schepper AM. Heterotaxy syndrome. Journal Belge de Radiologie 2004; 87: 158-9.

7. Himanshu A, Shireesh KM, Chaitanya DK, Ashok KV, 
Saurabh KS. Right isomerism with complex cardiac anomalies presenting with dysphagia-A case report. Radiology Case 2011; 5 (4): 1-9.

8. Chahed J, Mekki M, Aloui S, Hidouri S, Ksia A et al. Congenital pancreatic cyst with Ivemark II syndrome: a rare case. J Pediatr Surg 2012; 47: 33-6.
9. Matsuura K, et al. A case of right isomerism showing long survival without surgery. South Med J 2007; 100 (2): 218-21.

10. Eronen MP, Aittoma KAU, Kajantie EO, Sairanen HI, Pesone EJ. The Outcome of Patients with Right Atrial Isomerism is Poor. Pediatr Cardiol 2013; 34: 302-7. 